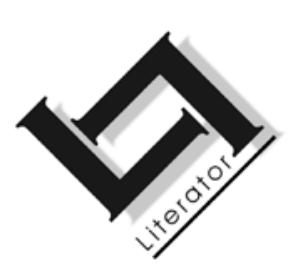

\title{
A philosophical interpretation of the significance of oral forms in I. Mabasa's novel Mapenzi (1999)
}

\author{
D.E. Mutasa
}

Department of African Languages

Unisa

PRETORIA

E-mail: mutasde@unisa.ac.za

\section{Muwati}

Department of African Languages \& Literature University of Zimbabwe

HARARE

E-mail: imuwati@arts.uz.ac.zw

\begin{abstract}
A philosophical interpretation of the significance of oral forms in I. Mabasa's novel Mapenzi (1999)

The article critically analyses the use of Shona oral art forms in I. Mabasa's novel "Mapenzi" ("Mad people"/"Foolish people"). It departs from the realisation that the writer identifies with Shona people's oral experiences in the form of songs, "bembera" (satiric poetry) and folktales among others. These oral art forms provide the means by which the writer overcomes both selfcensorship and real or imagined state censorship. The article advances the argument that Mabasa uses the Shona people's oral art forms in a manner that is ideologically and pedagogically empowering. This is consistent with the value thrust of Shona people's epistemological assumptions. The article comes to the conclusion that Mabasa's vision in the novel "Mapenzi" maintains the line between tradition and continuity.
\end{abstract}




\section{Opsomming}

\section{'n Filosofiese interpretasie van die belangrikheid van mondelinge vorms in I. Mabasa se roman Mapenzi (1999)}

Die artikel analiseer die gebruik van Shona mondelinge kunsvorms in I. Mabasa se roman "Mapenzi" ("Mal mense"/ "Dwase persone"), krities. Dit volg uit die besef dat die skrywer met die Shonas se mondelinge ervarings, in die vorm van onder andere liedjies, "bembera" (satiriese poësie) en volksliedjies identifiseer. Hierdie mondelinge kunsvorms verskaf die wyse waarop die skrywer selfsensorskap sowel as werklike of verbeelde staatsensorskap oorkom. Die artikel argumenteer dat Mabasa die Shonas se mondelinge kunsvorms gebruik op 'n wyse wat ideologies en pedagogies bemagtigend is. Dit stem ooreen met die kragtige waarde van die Shonas se epistemologiese aannames. Die gevolgtrekking waartoe gekom word, is dat Mabesa se visie in die roman, "Mapenzi", die lyn tussen tradisie en voortgang handhaaf.

\section{Introduction}

The artist in the traditional African milieu spoke for and to his community. His imagery, themes, symbolisms and forms were drawn from a communally accessible pool. He was heard. He made sense. (Chinweizu et al., 1985:241.)

The central concern in this article is the writer's use of Shona oral art forms in Mapenzi (1999). These art forms are part of the philosophy of life of the Shona people - their controlling consciousness which perfectly captures their "lived experiences". For many communities among African people, orature has functioned as a redoubtable bastion of people's struggles against the vagaries of life - internal and external. It has provided them with a potent technology that has made it possible for them to be subjects in the arena of active participation and contribution, giving and receiving. This is precisely the reason why our ancestors were astute enough to create art forms that largely revolve around the celebration and concretisation of hope and resilience. A number of Shona people's oral art forms serve to empower and embolden the human principle. The simple reason for such an outlook towards survival is that life is a challenge that demands courage. In other words, to live is to be courageous. The Acholi of Uganda have no kind words for cowards whom they tell, “O, coward, return into your mother's womb!" (P'bitek, 1986:26).

The Shona constitute the largest demographic group in Zimbabwe. Their experiences - past, present and future - have been and continue to find expression through oral art. The existence of other me- 
dia of expression has not been able to wipe out continued dependence on oral art forms. Creative writers, too, have similarly been inspired by the oral experience in articulating the Shona idiom. In a situation where direct and indirect censorship interferes with writers' creative liberties, orature proffers an alternative voice that allows writers to comment on sensitive issues. It is highly adaptable and can be given an allusive quality and fabricated setting which enables the author to comment on contemporary issues without seeming to do so.

It is in this context that Mabasa establishes a link with oral traditions which function as the vital nourishing supplement to his creative act. Such a creative modality is not only in sync with the creative demands of Afrocentricity, a theory that emphasises the placement of "African ideals at the centre of any analysis that involves African culture and behavior" (Asante, 1998:2), but is also ideologically and pedagogically empowering as it elevates orature to a position where, "it is the incontestable reservoir of the values, sensibilities, esthetics, and achievements of traditional African thought and imagination ... [while serving] as the ultimate foundation, guidepost and point of departure for a modern liberated African literature" (Chinweizu, 1985:2).

This article regards oral forms as a form of indigenous intellectual resources that African people use to get the best out of life. These intellectual resources as indicated by the writer's identification with them are deathless. It reasons that, writers who identify with oral forms simply contribute to the maintenance of an existential-continuum which is profoundly fundamental for the purposes of identity, location, space and place. A number of African scholars have pointed out the significance of orature as an empowering and legitimate medium in the struggle of the masses against their oppressors. They have also shown the transformative power of orature if responsibly and effectively used in literary art.

Seun Oyedola (2000:376-377), for instance, examines the influence of orality in the poetry of Niyi Osundare. He discusses the poet's use of "the narratives found in Yoruba oral tradition (epic, dirges, initiation songs, chants, incantations, magical formulaic patterns, etc.) ... to facilitate the development of his themes and style ... [As such], his notion of the poetic enterprise is transformative and redemptive, with a marked inclination to revolutionize society". Chiwome focuses on the discrepancy between Zimbabwean oral artists and literary artists' sensibilities and aesthetic orientation. He comes to the conclusion that oral artists have exuded an unrivalled commitment to the 
struggle for a better Zimbabwe. They have effectively marshalled oral resources to be a counter discourse to censorship.

So long as the gap between the rich and the poor continues to widen, literature which sensitizes the poor about their predicament will continue to be rare. The poor cannot rely on the technology of the rich to publish works which scrutinize the activities of the latter. The materially disadvantaged have to continue to rely on the song and other strategies under their control for self-expression. The oral word is stored in the mind where the censorman has no direct access to it. (Chiwome, 1998:158.)

Mabasa uses oral resources to escape censorship as he identifies with the vitality and hope that is synonymous with Shona epistemological foundations. His vision is not premised on the interrogation and revision of Shona oral forms. Rather, it revolves around the conceptualisation of oral art forms as a potent, liberative and lifeaffirming curriculum. The manner in which he uses orature in the novel Mapenzi falls squarely into what Achebe (1989:64) calls "... 'earthing' an electrical charge to ensure communal safety".

Orature is not past, traditional and fixated. It has its roots in the Shona past but continues to be created up to this day. It is the core of Shona people's philosophy. Any writer who effectively deploys it makes clear his/her intentions to the readers. In the words of Achebe (1989:62), it is dynamic, mobile and active, even aggressive. It is an arena where forces of life - visible and invisible, authentic and inauthentic, life-furthering and life-negating - find expression. Therefore, to perfectly and correctly establish a connective tissue between oneself and oral forms, it cannot be conceptualised as an assiduous escape into the past. To identify with the oral forms, which is an identification with Shona people's foundations of life, is what Baldwin (1963:71) persuasively presents as "to accept one's past - one's history - is not the same thing as drowning in it; it is learning how to use it".

We are largely concerned about oral forms in the novel because some of the Shona literary scholars have erroneously dismissed it as "naïve and sentimental" Shona novels that draw their inspiration from our oral traditions. On the other hand, they have celebrated those works that conveniently identify with Western literary techniques. These are some of the people who have been educated in colonial and neo-colonial institutions where they have been led to believe that to identify with African culture is congruous with living in 
the past. They fail to envisage that culture is neither an artefact, merely cosmetic nor something frozen in the past of human development. People who have used culture to develop their societies and build their nations, our ancestors for instance, are fully conscious of its power to develop.

\section{The oral forms in Mapenzi}

The novel, Mapenzi, is published almost two decades after Zimbabwe's independence in 1980. According to Gambahaya and Muhwati (2007:61)

Mapenzi centres on the mental and physical anguish experienced by Zimbabweans in the 1990s as result of a failing economy and abuse of political power. The story revolves around Hamundigone, a mentally traumatised former freedom fighter, who fearlessly blames the government and its failure to manage the economy for the problems that have reduced all characters in the novel to the level of mad or foolish people. These images aptly capture the destitution and desperation of the majority of Zimbabweans from the 1990s and beyond. The writer emphasises the vulnerable condition of his characters without blaming them for their condition, as has been largely the case with other creative writers.

One notices that various characters in the novel are victims of this economic and immoral political elitism. An unconscious reading of the novel can lead one to erroneously dismiss the novel as preoccupied with the victim mentality. This seeming victimhood is transformed into a combative and aggressive intellectual mode through various oral art forms which include bembera (traditional satiric poetry), Chimurenga war songs, contemporary sungura songs, and folktales. These art forms are carefully weaved into the fabric of the story to satirise leaders who abuse power and mismanage national resources. Such abuse and mismanagement leads to what the author projects as national neurosis. Mabasa is uncompromising in his stance.

His novel is the first Shona novel in post-independent Zimbabwe to articulate political issues in a manner that is overt. He links the problems that independent countries seem to be facing as well as an agglomeration of mapenzi (mad/ foolish people) to the behaviour of some of the arrogant and irresponsible leaders, which is likened to the behaviour of Zizi (Owl) mentioned in a folktale in this novel. 
After independence in 1980, a number of Shona writers seem to have internalised and institutionalised self-censorship to the extent of obliterating commitment to the people's cause. They seem to continue with the same creative patterns and trends inherited from the Rhodesian Literature Bureau, an organisation tasked with promoting the writing of literature in Shona and Ndebele languages during the colonial era. One way of promoting the writing of literature in indigenous languages was through the proposition of competition topics around which various writers would then develop their narratives. In most cases, the topics were on peripheral and trivial sociological themes which included gossip, witchcraft, laziness, drunkenness and love portions. Burning political issues were not addressed. This resulted in a literature that was not at one with the problems faced by people.

This trend continued after independence as the Rhodesia Literature Bureau was inherited intact. In line with the spirit of independence, it changed its name to the Zimbabwe Literature Bureau. There were no fundamental changes as the staff and operational policies remained the same. Writers in indigenous languages whose only avenue to publish was through the Zimbabwe Literature Bureau continued to avoid political issues that would offend the new black government. It is against this background that Mapenzi, written several years after independence, breaks with the established trend of avoiding direct political issues that blame the ruling elite for the problems in post-independence Zimbabwe.

Mabasa's literature is a literature that engages the oppressor in the trenches of intellectual warfare while fighting running literary battles with those in positions of unearned priviledge. It is a literature that shoots bullets. It is not incidental that the above oral art forms find expression through Hamundigone, the main character, a former freedom fighter and the author's voice of reason as well. The name Hamundigone (the invincible one) speaks of invincibility and a never-say-die attitude towards life. It is consistent with Shona nomenclature in which the process of naming is fundamental to survival and participation. Hamundigone is cast at the centre as a mentally deranged person. His mental trauma is a result of Zimbabwe's protracted struggle against colonialism in the 1970s. He becomes one of the many psychological victims of this war in Zimbabwean literature.

The projection of a mentally deranged person as a central character is an effective literary technique by the author as it affords him the opportunity to transcend self-censorship, which has the tendency of 
diluting and compromising creative commitment. He is shielded by his character because a mad person is known to deconstruct all forces of rational signification and say things which are considered taboo. As a former freedom fighter, he also gives authenticity to the author's version of a life dotted with poverty, suffering, abuse and other forms of immoral behaviour. Again, upenzi (madness) can also be visualised as a technique that the author strategically uses to interrogate both the official version of national history as well as the concept of independence. As a result, Mabasa can be regarded as an innovative writer.

\section{Use of Shona satiric poetry - bembera}

Through Hamundigone, Mabasa makes use of bembera to express people's despondency and disillusionment with some of their leaders. He also brings out the betrayal and abandonment of former freedom fighters, which is symbolic of the condition of the majority of people in the novel. Bembera is a type of traditional satiric Shona poetry that continues to be in vogue up to this day. It is an art that empowers the seemingly powerless and victimised with a fearless voice. For this reason, the author's choice of bembera is meant to empower the oppressed and disillusioned characters in the novel who stand for the masses of Zimbabwe. In the process of reciting bembera, the aggrieved or wronged makes public his/her disappointment. It is a facility that is meant to address social conflicts without direct physical confrontation in a context where harmony, balance and peace are critical determinants for social order. The reciter of bembera uses language that reverberates with discourses of self-significance. This is meant to inject fear, trepidation and convulsion into the intended target. Chiwome $(1996: 13,15)$ notes:

The bombastic [language] creates assonance and alliteration which make the poet awesome ... The grandiose hyperbolic discordant consonants create an impression of a formidable person. The lengthy epithets are accentuated in performance to contribute to the total intimidating rhythmic effect which can be humorous or intimidating, depending on the context.

In this novel, bembera becomes an effective form of social dialogue and social criticism that advertises people's anger and despondency. Hamundigone takes advantage of the presence of many people at Musika weBindura (Bindura terminus) to unleash his venom against various forces and other beings that torment him. This is consistent with bembera because choice of space, place and time is critical. The objective is to make not only the offender aware 
that he/she has been discovered, but to address as many people as possible.

Ndinzwe iwe! Ndati ndinzwe!

Ndinzwe ini inzwi rebenzi, ...

Tarisa zvako divi asi unondinzwa. (p. 8.) ${ }^{1}$

Listen to me you! I said listen to me!

Listen to me the voice of a mad person ...

Even if you look aside you will hear me.

The introduction is meant to draw, redirect and refocus people's attention at the terminus. It is meant to make sure that the assumed offender and other people do not miss out this verbal avalanche and other invectives. It is also an introduction that is loaded with anger and emotion as well as discourses of intimidation. The poem is strategically placed at the beginning of the novel to set the stage for the novel's uncompromising stance. In the novel, it is indeed intended to be a vituperative and vitiating attack on systems that dehumanise people. The reasons that plunge most of the characters like Kundai, Magi, Maud, Vincent and others into an unfathomable lapse of vitality and immorality as well as degeneration into ideological captivity and mass neurosis are captured in this introductory poem. Kundai and Magi are two young women in the novel who represent the majority of the University of Zimbabwe's female students. As a result of reduced and yet much-needed government support, in the form of grants and loans, they resort to prostitution in order to survive. Vincent is an unemployed man, who survives by selling outlawed drugs like dagga while Maud is a widow who earns a living through cross-border business.

At this point, it can be argued that the author makes use of oral forms as an effective literary style. This style not only enhances the aesthetic beauty of his work, but also elevates his novel into a profoundly fundamental "pedagogy of the oppressed", who are represented by the above mentioned suffering characters in the novel. It is a way of pedagogical and ideological empowerment. Mobilisation of human consciousness and the national human factor element requires the adoption of discourses that are unassailably linked with the people's lived experiences and their exigencies of existence. Bembera is part of this. Mabasa achieves both innovation of content and form. In this article, innovation is understood not as "a dreary

1 References only indicated by a page number refers to Mbasa (1999). 
dead end of meaningless experimentation, arbitrary innovation, or the lunatic's dance of esoteric, privatist aestheticism for its own sake. [It] is a tool not an end, to be applied with intelligent restraint and firmly disciplined in service to enhanced meaning and heightened communication." (Thelwell 1990:6.)

Hamundigone makes his invincibility and fearlessness explicit through the following combative words:

Handisi shumba iri papeji mubhuku

Yaunorega vana vachibata muromo.

Kagandanga kari mandiri ingozi yerombe,

Kanotaura zvinokushaisa hope usiku. (p. 9.)

Do not take me for a lion on a book page

That you allow children to play with.

The fighter in me resembles the aggrieved spirit of a pauper,

He lets out things that make you lose sleep.

Hamundigone, who represents the voice of the oppressed and deprived, reaffirms people's ability to act. The declaration that he is not a passive and lifeless lion is at the same time a confession of his aggressiveness, combativeness and readiness to do battle. It is noteworthy that despite the oppression and betrayal, he still has the ability to transcend forces that dehumanise him. In other words, this is a warning that he, together with others in his class must not be taken for granted. Unlike some Zimbabwean writers who depict their characters as having reached the ceiling of their existence, and as having been totally elbowed out of the processes of existence, Mabasa through the image of Hamundigone, depicts him as a bundle of energy. Some of these writers view society through the lenses of victimhood, vulnerability, hopelessness and helplessness.

However, through the adoption and adaptation of Shona people's indigenous oral forms, the author restores and bestows upon the people their visibility and authenticity. These are crucial when it comes to participation. His discourses are premised on the philosophies that recognise participation as the sine qua non and modus operandi for liberation and development. We estimate that this kind of combative and never-say-die vision has been made possible by the author's identification with orature. To a very large extent, Shona orature gyrates around the principles that enhance optimism. It is not founded on the

... ascetic tradition, the attempted fleeing from life, from full participation in the tremendous and deepest challenges of the life- 
process with its risks and dangers, with its joys of success and brief sorrows of failure and loss ... [but that] the African tradition, lived and lives in the thick of battle of life; here and now (P'bitek, 1986:21).

In the context of bembera, especially as shown through Hamundigone, the overarching concern is not to exhibit fear and a profound loss of vitality. Rather, it is to show that the wronged is not afraid and is indeed prepared for any action. From the above discussion, it is discernible that one way of circumventing nihilism and a host of other philosophies related to life-negation and hope abandonment, is to responsibly adopt and embrace indigenous oral forms as the brick and mortar in the construction of a resonant national literary edifice.

In a novel where power abuse and suppression of people's liberties are rampant, as shown through Garanowako, now a member of parliament, and others in positions of authority who abuse funds meant for war victims, Mabasa does not compete, as if in a race, to present the oppressed as hopelessly powerless and irretrievably trapped. To adopt that style of authorship, would equate to being a participant in the very systems that strangulate and deny people a life that is a feast of existence. The greatest gift any responsible writer can give to his/her readers is an affirmation of the fact that they are subjects and not objects to be acted upon. This gift is part of the "relocation, the repositioning of the African in a place of agency where instead of being spectator to others, African voices are heard in the full meaning of [life]" (Asante, 1999:ix). It is precisely for this reason that Thelwell (1987:231) dissuades African writers and critics from embracing defeatist attitudes even when conditions seem to be pathologically debilitating:

An honest novel cannot proceed out of a glib, fashionable coffee house cynicism in which everything is beyond human effort. It is rather, predicated on the assumption that there is a future for which to struggle, that conditions however grim are not beyond the reach of people's will, intelligence and decency, and that the writing and reading of such novels are not only testament to that faith, but are an integral part of that struggle.

Towards the end of the poem, the listener is made aware of the problems that have divested the reciter of happiness. The problems revolve around the rabid betrayal of his wishes by some named and unnamed political leaders in the novel. It is clear from the anguished voice that he and others sacrificed their lives for real change. The sacrifice was based on a specific set of practical goals which in- 
cluded freedom of choice and expression, access to decent housing, health, food and many other basics of life which make life enjoyable.

Zvinofadza here?

Ndati zvinofadza here vakomana imi?

Poto yakatsva ichibika sadza pamoto,

Asi kutebhuru kukaenda ndiro dzaive musherefu? (p. 9.)

Is it pleasing?

I said is it pleasing you boys?

The pot was burnt while cooking sadza,

But the table was graced by plates from the shelf.

Poto ("cooking pot") stands for the majority of people who sacrificed their lives and combined their vitalities in order to attain unalloyed freedom from the suppressive colonial regime. Sadza, which is Zimbabwe's staple food, represents the life-sustaining and life-giving programmes that people expected to get after the attainment of independence. It also symbolises expectations of a healthy life that is characterised by plenty and happiness because it is the essential supposed duty of government to make its people happy. This fact is corroborated by Shona people's sayings in recognition of the profundity of sadza. Sadza muponesi, Jena muponesi, chibataura ("sadza, giver of life", "securer of intestines"). Pamoto ("on fire") represents the pain, commitment and endurance of the people. Ndiro dzaive musherefu (plates from the shelf) is an expression of the political opportunists and other irresponsible leaders who betrayed people soon after independence. This is part of the theme of politics without morality in this novel. It is this betrayal, for instance, which has engendered the mass neurosis that is the core of the novel Mapenzi. In the case of Hamundigone, this pain manifests itself through the frightening scars on his back as well as the serious mental injuries caused by the war. It is also this irresponsible type of leadership presented in the novel that has driven the reciter to unleash his vitriolic venom using bembera. By using bembera, the author targets into an oral form that is well known to people who use it. The images used such as sadza, pamoto, ndiro, musherefu and tebhuru are all common types of images that the Shona people are familiar with - hence the effectiveness of this type of oral form.

Hamundigone's use of bembera becomes fitting in that it increases people's awareness that his deplorable condition, together with theirs, is partly attributable to the existence of a class of oppressors among them. This kind of awareness and self-knowledge "by the victim means in the first place an awareness that oppression exists, 
that the victim has fallen from a great height of glory or promise into the present depths ... [and] the victim must know who the enemy is" (Achebe, 1988:6). As a public address system, the mood in bembera is brazenly combative and aggressive. It does not camouflage human commitment to the goal of social and political transformation. This is the case, because we strongly believe that the human condition must be viewed from the perspective of change, not fixity. As indicated before, it is because of the writer's careful and responsible use of oral forms that he does not visualise humanity as an amorphous mass of lifeless, hopeless and powerless beings. While other poems in this novel reflect the vulnerability of characters, it is largely the oral forms that are dispensed by Hamundigone, the author's voice of reason, which are empowering. It is also an effective strategy by the writer to make sure that Hamundigone, the suffering former combatant speaks on behalf of the other characters.

\section{Sungura music and Chimurenga Shona songs}

While bembera exposes the source of disenchantment and mass neurosis in this novel, songs also convey the same spirit where they blend anger and possibilities of transcendence. Mabasa uses popular sungura songs and Chimurenga war songs. Sungura is a form of Zimbabwean music that is largely expressed in indigenous languages - Shona, Ndebele, Kalanga and others. It is the equivalent of Mbaqanga, Kwaito and Pansula in South Africa and R\&B in America. This makes it readily available and accessible to indigenous people. It is also performed during live shows and played on Zimbabwe's national radio. The author selects the music of Simon Chimbetu, a former freedom fighter of Zimbabwe's armed struggle against colonialism. The song, Hope iyi ("This dream") is repeatedly used throughout the novel.

The philosophy that underpins the song is derived from Shona historiography, even though it pulsates with the rhythmic and philosophic incantation of Martin Luther King (Jr)'s "I have a dream". Coincidentally, it is also brought to the readers' attention by Hamundigone, the central character. Both Chimbetu and Hamundigone are former freedom fighters who seem to be expressing disgust with systems that are unpopular because they bring torment. It reasons, therefore, that Mabasa intends to maximise the reader's awareness of the manner in which the elite in the novel have abandoned the people in pursuit of decadent, nefarious and invidious self-aggrandising agendas. He is questioning the legitimacy of an elite that ma- 
nages national affairs at the expense of characters like Hamundigone who laid down their lives for positive change.

In the song, Mabasa chooses the excerpt which reads kutuka kwavaniota uku kuchapera ("the way they scorn us will one day come to an end"). The tone is that of pain, anger and despair. However, it is not pain that leads nowhere, nor anger that is self-immolating, nor despair that is self-obliterating. It is a song that is futuristic, whose strength lies in the affirmation of hope and the impermanence of abusive or oppressive regimes. For instance, in one of the numerous direct references to Zimbabwe's ageing leadership, Kundai, a university student is able to empower her audience with a firm understanding that things will be allright once the current generation of ageing politicians leaves the platform. She says:

Manje zvevamwe ndezvekungoda kuba mari. Pamwe zvinhu zvichachinja kana madhara ese akarwa hondo abva, tave kupa munhu position because he or she is competent, kwete some of the political appointments because people were at the front together. (p. 106.)

Others just want to use the positions to enable them to steal money. Maybe things will change if all the old men who fought in the liberation war are gone. In that context, a person will get a job because he or she is competent, not some of the political appointments because people were at the front together.

The ability to see into the future is consistent with the ability to go beyond narrow-mindedness and near-sightedness. It is one mechanism of overcoming victimhood. Hamundigone frequently makes reference to this song. It is clear in the eyes of Hamundigone that life is a long distance race, and all people graciously bequeathed with this life are long distance runners. As such, it is fundamental not to lose focus of the race. Chimbetu's song is based on an invincible reassurance of eventual freedom. It is in line with the deathless teachings of the great African-American historian, Dubois (Foner, 1970:172, 173), who at one point reassuringly said:

Courage, brothers! The battle for humanity is not lost or losing. All across the skies sit signs of promise ... The morning breaks over blood-stained hills. We must not falter, we may not shrink. Above are the everlasting stars.

Despite the current anger and impoverishment, the song pampers the people with an unassailable and reassuring optimism. While the song might be silent on the path of action that is needed to put an 
end on kutuka (scorn), we believe that optimism is a paramount requisite in any struggle for freedom and human redemption. People who lose optimism and hope invariably lose the zest to live to see tomorrow. Put differently, the absence of optimism stands as an indelible marker of social death, a phenomenon that works to the advantage of the oppressor.

The excerpt kutuka kwavaniota uku kuchapera is a profound political package. Kutuka is a Shona verb which, in a literal sense, means "to insult, scorn, to mock or to shout at". In this song, and also consonant with the theme in this novel, it is a concept that denotes oppressiveness and excessive abuse of political power, mismanagement of public funds and the betrayal of people's aspirations and wishes for a happy life. The novel is replete with examples that epitomise kutuka. The most consistent example is the manner in which the characters have been reduced to the level of animals. Hamundigone, the former combatant is forced by hunger to ransack garbage bins in search of food. This happens despite the fact that he had earlier on met one of the characters, Garanowako, a member of parliament who could have addressed his precarious situation. However, Garanowako, instead of helping Hamundigone, his former colleague from the war calls for security.

Akanditarisa semunhu aona marutsi pasutu yake... 'Hey Mr.

Driver, itai kuti security ibvise munhu uyu pano!' (p. 19.)

He glared at me like a person who has seen vomit on his suit ...

'Hey Mr Driver, let security remove this person from here!'

The arrogance exhibited by Garanowako who is a leader of the people, is part of the kutuka concept. The manner in which Hamundigone is treated humiliates and dehumanises him as evidenced by the way he becomes numbed with shame. Also the abuse of national funds that were meant for former combatants shows the insensitivity and corruption within the top echelons of power which is said to be responsible for upenzi (madness/foolish behaviour) in this novel. The funds are looted by undeserving leaders earlier referred to as ndiro dzaive musherefu while real beneficiaries poto yakatsva ichibika sadza pamoto like Hamundigone get nothing. Hamundigone expresses this senseless abuse of public funds by leaders when he says: Yekurwa hondo here? Handisati, ndakangomirirawo nanhasi. Vamwe vakatopiwa katatu-katatu. (p. 27.) ("You mean that for fighting? I am still waiting. Some have received it three times each.") Magi, one of the characters, also brings out this nonchalant abuse when she informs us that: 
... mamwe mashefu akazoba mari achiti they were suffering from war traumas ... Vamwe vacho havana kana nekutomboenda kuhondo kwacho, kana nepfuti dzacho havadzizivi. Vaitogocha nyama zvavo munanaBotswana nanaZambia umu, hondo yapera vakazouya vachitiratidza madzvanga avakatsva nenyama yemabraai vachiti aive mavanga emabara emuvengi. (p. 106.)

Some high ranking government officials looted funds meant for genuine war veterans claiming they were suffering from war traumas ... Some of them never went to war and do not even know what a gun looks like. They were busy braaiing meat in Botswana and Zambia. After the war, they came back showing us scars obtained from braaiing meat saying they were remnants of the enemy.

This oppressiveness which is expressed as kutuka in the song is part of the conveyor belt of upenzi which leads to mapenzi. It leads to the destruction of life as shown through the rampant prostitution among a university's female students represented by Magi, Kundai and others whose names are not given. They are plunged into immoral behaviour because of economic regression. Characters like Eddie end up staying with their in-laws because they cannot secure jobs to sustain them. Among the Shona people and most African communities, the relationship between a son-in-law and a mother-inlaw is characterised by distance. Such distance is crucial in the maintenance of a sound relationship based on dignity, respect and restraint. Mbiti (1969:143) elaborates on this existential necessity when he reminds us that:

In African societies, the kinship system involves among other things, relationships in which physical avoidance between given individuals is carefully observed. For example, this is the case between a man and his mother-in-law ... Physical avoidance protects the individuals concerned from sexual contact.

In Mapenzi, some citizens like Vincent, engage in illicit drug peddling because there are no jobs while theft is rampant. Human beings are portrayed competing with dogs for access to garbage bins. As the author puts it, this behaviour is a result of the manner in which the national economy has been mismanaged. The gross violation of national resources which dehumanises people is what leads Hamundigone to borrow Chimbetu's song. In this regard, the mismanagement of resources constitutes kutuka. In such a context as shown in this novel, it is not possible to uphold morality because survival takes precedence over morality. This is the reason why Garvey 
(1986:13) says that "hungry men [and women] have no respect for law, authority, [morality and] human life".

What is most intriguing about this song is the manner in which it acknowledges the existence of oppression as a dehumanising system. Despite the existence of oppression, it does not drag and burden humanity with needless and mindless pessimism and hopelessness. Rather, it places emphasis on vigilance and futurism in long term strategic planning. It socialises humanity into a scheme where the ability to see beyond the blocking and limiting horizons imposed on us by our oppressors, is an indispensable weapon in the ultimate realisation of dignity. This is consistent with African and Shona people's ontological and epistemological assumptions where defeatism and surrender are not at all immediate options.

Mabasa's use of such oral forms is a potent weapon in human factor development. It becomes appropriate when one takes into consideration the fact that the kind of life that Mabasa is depicting is a life that has been fundamentally mutilated and battered. In fact, it is a life that abounds with images of human factor decay. Orature becomes a tool that affords his novel a transcendental outlook. Transcendentalism is crucial to life as a negation of victimhood and vulnerability. Ephraim (2003:132) has spoken of transcendence thus:

But since self-transcendence is necessary for even the taste of freedom, then those incapable of the existential 'upheaval' and new birth must somehow be shown the way [to see into the future].

The transcendental dimension of the song pertains to both the abusers of privilege like Garanowako and the oppressed in the form of Hamundigone, Vincent and others. The oppressors are warned that oppression, in whatever form, is temporary because it is not man's ontological vocation. In this regard, it is a caution to see beyond the present comfort that is derived from the people's sorrows.

While the song Hope iyi emphasises the kutuka concept, another Chimurenga song by Thomas Mapfumo, a Zimbabwean artist, expresses the contradictions that characterise the party which led the struggle for independence and what it stands for now. These contradictions are part of kutuka. In the novel, the party seems to have abandoned the egalitarian principles that it represented during the war. It used to be an emblem of people's hopes and aspirations for independence and their future lives. However, now it is depicted as a party that simply stands for the Fanonian pitfalls of national 
consciousness where "the party has made itself into a screen between the masses and the leaders" (Fanon, 1967:137). Mabasa uses pastoral imagery to describe the behaviour of this political party. This is indicated by Hamundigone who says:

Vanopenga vanoonekwa hupenzi hwavo kunge vapfanha vari kumafuro vanoti ivo vakwidzwa mumuti kuti vatemhere vari pasi shumha ivo vodyira mumuti vachingodonhedza matsengwarengwa. (p. 134.)

Those who are mad/foolish behave like young boys herding cattle who are hoisted up the tree by their colleagues to get fruits for all but decide to eat alone while throwing down remains.

This betrayal and pain finds expression through Hamundigone's spontaneous reaction when he listens to a Chimurenga song called Gwindinwgi rine Shumba. He involuntarily finds himself crying when the song is played on radio. The song is as follows:

Nharo hapana, tiri kutonga isu

Tose vatema.

Takazviudzwa naVaMugabe.

Zanu nevanhu, Vanhu chiiko.

Zanu vanhu, vanhu iZanu ...

Vakabva vatanga kuchema. (p. 132.)

No doubt, we are ruling

All black people.

Mugabe told us this.

Zanu and the people, what are people.

Zanu is the people's party and people are Zanu ...

After listening to the song, he started crying.

The pain is exacerbated by the fact that as a former combatant who once defended this party and the "progressive" ideology it is said to have once represented, he finds himself jobless, hungry and ransacking garbage bins and above all, tormented by ghosts and other dehumanising experiences from the liberation war. Since Hamundigone consistently recites Chimbetu's song Hope iyi, the party is projected as a symbol of kutuka. This realisation is very painful and dehumanising. It is also responsible for the various forms of upenzi in this novel. 


\section{Use of the Shona folktale narrative}

Apart from songs, Mabasa also embraces Shona people's oral narratives in the form of a folktale called Zizi nedzimwe shiri ("Owl and other birds"). The folktale "expresses man's mission, namely, to participate in and thereby to transfigure his world; to make this world conform to his vision of a habitat fit for man as such, a home for himself and his putatively homeless and abject kin ..." (Ephraim: 2003:138). In this folktale, Zizi (Owl) is king of all birds. He derives his power from the fact that he feigns to be the only bird with "horns". He therefore abuses this assumed privilege and makes the bird kingdom a virtual penitentiary. All birds have to bring him food while he sleeps. One day during a meeting, Nhengure sat closely to Zizi and carefully analysed his physiology. He realised that Zizi did not have any horns but had feathers which he used to intimidate other birds with. From then onwards, Nhengure challenged Zizi and engaged him in a fight. Zizi cried and ran away. In the end, there was happiness for all birds. Zizi akachema achitiza, shiri dzese dzikafara. (p. 132.) ("Zizi cried and ran away and the other birds partied and celebrated.")

Folktales are part of the oral forms that were and are used to mould and direct perception and consciousness. They also directed human participation. Obviously, those who have been mis-schooled misinterpret these folktales as rudiments of childish and fetishist psychology and "underdeveloped spirit, still involved in the conditions of mere nature" (Hegel, 1952:199). As Africans who are rooted in the oral story-telling traditions, we refute this as we interpret with Salivating and ecstatic admiration those works that are rooted in Shona/African creative traditions. The above folktale is a typical "revolutionary pedagogy of the oppressed" where there is only one destiny for mankind - freedom. It is a straightforward existential instruction to any person to desist "from allowing, through carelessness and moral cowardice, any social evil to grow" (Dubois, 1969: 199).

By blending this folktale into his narrative, Mabasa makes clear his vision and commitment as a "writer in politics" whose volition is to reassure society that, no matter how debilitating, oppression can be overcome. He reflects what Achebe (1989:74) says "most African writers write out of an African experience and a commitment to an African destiny". In the folktale, the birds stand for the oppressed while Zizi represents the abusive and arrogant oppressors. Like most of the progressive oral art forms in this novel, it is told by Hamundigone. Interestingly, he narrates this tale to a young man, 
Reuben, who is his sister's son. One can hazard to say that this gesture is a form of promise, continuity and a reassuring pedagogy that the spirit of struggle will continue. It is similar to Katiyo's Son of the soil (1976) where the death of the old man, himself a visionary and fighter, is succeeded by the birth of an equally vivacious child whose mission is to perpetuate the spirit of struggle.

The overarching pedagogy in the above folktale, which as stated above, is a "pedagogy of the oppressed" lies squarely in the reaffirmation of the age-old realisation that the oppressed are their own liberators. They must negate and indeed transcend defeatism and surrender. This is exactly what the birds do because they do not abandon the search for freedom and liberty despite the threat posed by the domineering Zizi. When the oppressed embrace vulnerability, victimhood, helplessness, hopelessness and meaninglessness as new social ideals they become their own oppressors. In fact, they make the oppressors' burden of oppressing and dehumanising them less demanding. It is for this reason that we put forth the proposition that the folktale of Zizi nedzimwe Shiri is resonant with vibrations of the creation of a new people, with a new humanity.

The folktale proffers a reverberating and refreshing alternative to the morbid and moribund consciousness that has become symptomatic with some works in Zimbabwean literature whose thrust is modernist existential nihilism. The triumph over the oppressive Zizi, which is a pedagogy of the oppressed, represents an extricating philosophy from the depths of nothingness. It is a lesson for the oppressed to inexhaustibly strive towards the creation of men and women who are not overwhelmed by philosophies of nothingness. It is a marker of man's triumph over invisibility, inauthenticity, and non-beingness while rediscovering authenticity, visibility and beingness.

The birds' freedom is born out of physical confrontation. By narrating the above folktale, Hamundigone seems to be hinting that his condition cannot be changed outside the context of struggle. This necessarily entails that the oppressed people can never experience freedom unless they use force to overwhelm their oppressors. This is a fact all oppressed people have to contend with because oppression stands for unyielding violence, which Fanon (1967) has referred to as an unthinking machine which can only yield when confronted with greater violence. Many revolutionary scholars have emphasised violence as the sine qua non for freedom. One such scholar is Freire (1970:29) who states that: 
Freedom is acquired by conquest, not by gift. It must be pursued constantly and responsibly. Freedom is not an idea located outside of man; nor is it an idea which becomes myth. It is rather the indispensable condition for the quest of human completion.

Freire emphasises the need for constant and responsible pursuit of freedom. The birds took their time studying Zizi, the oppressor, until such a time when it was convenient to strike. Therefore, it is mischievous to label the oppressed people cowards when conditions are not yet right for them to institute a revolution. The great AfricanAmerican historian Frederick Douglass had also long realised in 1857 that:

The whole history of human liberty shows that all concessions yet made to her august claims, have been born of earnest struggle. This struggle may be a moral one, or it may be a physical one, and it may be both moral and physical, but it must be a struggle. Power concedes nothing without demand. It never did and it never will. (Gordon, 1997:1.)

The folktale is strategically placed towards the end of the novel when all the problems bedevilling society as well as their sources have been highlighted. It suggests the possible solution to issues raised in the satiric poem, bembera, as well as kutuka kwavaniota. In this regard, the various oral art forms in this novel intricately concatenate to provide a moving picture of the problems and solutions to the existential nightmare that torments characters in the novel.

For that reason, Mapenzi becomes a novel that does not only confine itself to the portrayal of the human object position but more importantly, it shows human beings as subjects of life. This is articulated through various oral art forms whose thrust is triumphalism and transcendence. The folktale, in particular, shows that the right to defend life, which is a right to self-defence, is a moral obligation that must be pursued at all costs. This is necessary because "self-defence is a natural, perhaps even an instinctive reaction of all living organisms confronted with imminent injury" (Ramose, 1999:ii). Such an act is indispensable because oppressive systems tend to monopolise the right to self-defence. The gesture shown by Nhengure, who is representative of all birds, is a celebration of the human project over forces inimical to human existence and the realisation of life as a great party. It is also a celebration of approach-behaviour as opposed to avoidance-behaviour. Avoidance-behaviour, which is consistent with withdrawal and resignation functions subversively 
and defectively for the suffering but effectively for those who thrive on oppression.

\section{Conclusion}

The article consistently argues that the conceptual thrust in Mapenzi is futuristic, reassuring and empowering. The author makes use of Shona oral forms to parade human possibilities and unlimited potentialities. Mabasa deploys orature in order to interrogate and illuminate the present, while showing that conditions of life today, however grim are not untransformable. This creative gesture becomes a responsible act of mobilising society and constructing a sociological foundation based on hope in a novel where the temptation to embrace hopelessness is highly palpable. Mabasa's exuberant vision in this novel, as epitomised through oral art forms, is incandescent with the kind of intellectual might that

... trains the intellectual eye to see the broad canvas of fundamental human concerns. This is the kind of [vision] that Paulo Freire, in majestic simplicity, has described as a pedagogy of the oppressed, the kind that invests an individual with a profound sense of commitment to human betterment, and hence to the humanization of man. This kind of [vision] leads to enlightenment, which brings with it always a sense of urgency to do the right, to bring about change. This kind of [vision] is what has always been feared by those ... who crucified Christ, and those who assassinated Martin Luther King and Malcom X. (Ephraim, 2003:258.)

As pointed out in the preceding argument, Mapenzi becomes a typical pedagogy of the oppressed which calls for critical analysis and action. This is made possible by the author's conscientious use of Shona people's oral forms and it is against this background that the article argues that Mabasa employs Shona oral art forms in a manner that underscores Shona people's position as agency. Through Hamundigone, he seems to reaffirm their ability to overcome challenges that they encounter in life. In this regard, the problems that different characters experience are not projected as a threat, but a challenge that requires commitment and responsible action.

\section{List of references}

ACHEBE, C. 1988. Spelling our proper name. (In Chametzky, J., ed. Black writers redefine the struggle: a tribute to James Baldwin. Amherst: Institute for Advanced Study in the Humanities. p. 5-12.) 
ACHEBE, C. 1989. Hopes and impediments: selected essays. New York: Anchor Books.

ASANTE, M. 1998. The Afrocentric idea. Philadelphia: Temple University Press.

ASANTE, M. 1999. The painful demise of eurocentrism: an Afrocentric response to critics. Trenton: Africa World Press.

BALDWIN, J. 1963. The fire next time. Harmondsworth: Penguin Books.

CHINWEIZU E. 1985. Toward the decolonization of African literature, African poetry and their critics. London: KPI.

CHIWOME, E.M. 1996. A critical history of Shona poetry. Harare: University of Zimbabwe Publications.

CHIWOME, E.M. 1998. The response of Zimbabwean oral and literary artists to missionary teachers. (In Walters T.S., ed. Orality, literacy, and the fictive imagination: African and diasporan literatures. Michigan: Bedford Publishers. p. 147-161.)

DUBOIS, W.E. 1969. The suppression of the slave trade to the United States 1638-1870. Baton Rouge: Louisiana State University Press.

EPHRAIM, C.W. 2003. The pathology of eurocentrism: the burden and responsibility of being black. Trenton: Africa World Press.

FANON, F. 1967. The wretched of the earth. Harmondsworth: Penguin.

FONER, P.S., ed. 1970. W.E.B. du Bois speaks: 1880-1919. With tribute by Martin Luther King, Jr. New York: Pathfinder.

FREIRE, P. 1970. Pedagogy of the oppressed. New York: The Continuum Press.

GAMBAHAYA, Z. \& MUHWATI, I. 2007. Critical perspectives on morality and the human condition in Ndebele and Shona novelistic discourse. Nawa journal of language and communication, 1(2):59-73.

GARVEY, M. 1986. The philosophy and opinions of Marcus Garvey. (In Garvey, A.J., ed. Africa for the Africans. Dover: The Majority Press.)

GORDON, L.R 1997. Black existential philosophy. (In Gordon, L., ed. Existence in black: an anthology of black existential philosophy. New York: Routledge. p. 1-9.)

HEGEL, G.W.F. 1952. The philosophy of history. Chicago: Encyclopaedia Britannica.

MABASA, I. 1999. Mapenzi. Harare: College Press.

MBITI, J. 1969. African religions and philosophy. Portsmouth: Heinemann.

OYEDOLA, S. 2000. Orality in the poetry of Niyi Osundare. Journal of cultural studies, 2(1):376-383.

P'BITEK, O. 1986. Artist the ruler: essays on art and culture. Nairobi: Heinemann.

RAMOSE, M. 1999. African philosophy through ubuntu. Harare: Mond Books.

THELWELL, M. 1987. Duties, pleasures, and conflicts: essays in struggle. Amherst: University of Massachusetts Press.

THELWELL. M. 1990. Eagle on Iroko. Opening address: Nsukka, University of Nigeria, Feb. 12. 


\section{Key concepts:}

hope

liberation

Mabasa, I.: Mapenzi

oppression

Shona/African oral art

Kernbegrippe:

bevryding

hoop

Mabasa, I.: Mapenzi

onderdrukking

Shona/African modelinge kuns 
